In spite of those changes of various enzyme activities and glycogen content both in liver and muscle of the rats with experimental thyroid disorders, in general, blood glucose level was maintained within normal level.

But by hydrocortisone administeration to thyroxine treated rats, levels of FDPase and G-6-Pase activities in the rat liver elevated more significantly than those in thyroxine-treated rat, and consequently blood glucose level elevated markedly.

From the above mentioned results, it is suggested that blood glucose level and carbohydrate metabolism in thyroid disorders may be regulated by co-operation of various factors such as glucose utilization in peripheral tissue, glucose production of the liver and functions of adrenal and other endcrine organs.

\title{
Studies on the Clinical Application of TSH Bioassays
}

\author{
Yasuhisa TOKI \\ The 1st Department of Medicine, Osaka University Medical School \\ (Director : Professor Tsuneo Yoshida)
}

TSH bioassays were experimentally carried out in view of the possibility of their clinical application, both in vivo and in vitro.

The results were as follows:

1) In the method using ${ }^{32} \mathrm{P}$ uptake with the thyroid gland of chick, the best dose-response curves were obtained (with the mean $\lambda$ of 0.44 and the sensitivity of $25 \mathrm{mJSu}$.) by measuring the total thyroidal radioactivity 6 hours after the simultaneous intraperitoneal administration of TSH and ${ }^{32} \mathrm{P}$.

2) In the method using the release of ${ }^{131}$ I-labeled thyroid hormone after the administration of TSH in mouse, the precision of the dose-response curve was improved by the administration of TSH 24 hours after L-thyroxine and ${ }^{121} \mathrm{I}$ were injected. The mean $\lambda$ value was 0.24 , and the detectable range of TSH, $1 \sim 16 \mathrm{mJSu}$.

3) In the method based on the release of inorganic radioiodine with bovine thyroid tissue slices in vitro, a positive correlation between the thyroidal ${ }^{131} \mathrm{I}$ uptake rate $(U)$ in the uptake phase and the thyroidal accumulation rate $\left[U^{\prime}(=100\right.$-release rate) $]$ in the release phase was observed; and using $\mathrm{U}^{\prime} / \mathrm{U}$ as a new index of this method, augmentation of the precision was obtained with a mean $\lambda$ of 0.33 , being better than that obtained by using the ${ }^{131} \mathrm{I}$ release rate. The detectable range of TSH was $0.1 \sim 10.0$ uJSu.

4) By the modified assay technique for TSH based on the release of ${ }^{131} \mathrm{I}$ with bovine thyroid tissue slices (in vitro) and the release of ${ }^{131}$ I-labelled thyroid hormone in mouse (in vivo), correlation between the dose-response relation of Standard (Pig) and Human (Pituitary) TSH, and the assay value of hypophyseal TSH, measured by the two method, were investigated.

A approximate parallel relationship between the dose-response curve of standard and human TSH, and between the in vitro and in vivo TSH value per pituitary was observed. 


\title{
TSH Bioassay の臨床応用に関する基礎的研究
}

\author{
大渡大学医学部第一内科 (主任 吉田常雄教授) \\ 土 岐泰 久
}

(昭和 37 年 2 月 22 日受付)

緒

言

Loeb $^{1)}$ 及び Aron $^{2)}$ が甲状腺機能を 促進する物質として下垂体より甲状腺刺战ホルモン (TSH) の分泌 を指摘して以来，その物質の生物学的並びに化学的研究が行なわれてきたが，今日尚その化学的構造が完全 には明らかでなく，その測定には專ら生物学的検定法が用いられている。TSH の生物学的検定法には甲状 腺の形態学的変化を指標とする方法 ${ }^{344) 5}$ )を初めとして多くの報告が見られるが，ての形態の変化による判定 には主観的因子が介入し易い為，迅速に実施出来，且つ主観性の入り難い Bioassay として ${ }^{131} \mathrm{I}$ 又は ${ }^{32} \mathrm{P}$ を利用する方法に就いて現今種々の検討が行なわれてはいる。しかし，尚充分满足すべき方法はない。

周知の如く甲状腺疾患の病態生理及び TSH の分泌機構の解明には体液中の TSH 測定が必要欠くべか らざるものとされ，その為には感度及び精度の勝れた測定方法を確立する必要がある。そてで私は現在実用

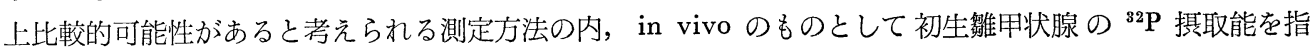
標とした方法及びマウスの血中 ${ }^{13} \mathrm{I} I$ 放出を指標とした方法を，更に in vitro のものとして牛甲状腺切片の ヨード代謝を指標とした方法を選び, 夫々の Bioassay に就いて基整的検討と改良を加え, 更にその臨床応 用への可能性を検索せんが為, in vivo 及び in vitro の方法で標準 TSH と人 TSH との反応性の関係 を追求し，更に同一検体に就いて TSH 測定を行ない両者を比較検討した。

\section{I 初生雊甲状腺の ${ }^{32} \mathbf{P}$ 摂取能を指標とした TSH Bioassay に関する検討}

初生維甲状腺の ${ }^{32} \mathrm{P}$ 摂取能を指標とせる TSH Bioassay は (rooke \& Matthews, ${ }^{6}$ ， Lamberg) 等によつ て始められ，更に Greenspan ${ }^{8)}$ は TSH を心藏内に投与する改良法を発表した。本 Bioassay の基礎的検 討に関する報告 ${ }^{910) 11)}$ もみられるが，TSH と ${ }^{32} \mathrm{P}$ の投与方法と投与の時間的関係及び指標の選び方等に就 いては，尚問題点が多いので両者を比較して検討を行なつた。

\section{1. 実験材料並びに方法}

\section{1) 検定動物}

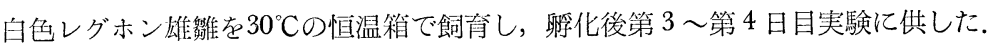

2) ${ }^{32} \mathrm{p}$

生食水 $0.5 \mathrm{ml}$. 中に $10 \sim 25 \mu \mathrm{c}$. を含偖せる様に調整し腹腔内に注射した.

\section{3) 標準 TSH}

Pretiron (Schering 社製) 在生食水にて所要濃度に稀釉し, 腹腔内投与の場合は $1 \mathrm{ml}$., 心内投与の場合 は $0.1 \mathrm{ml}$ ，を，ての際又対照としては生食水のみを注射した。

\section{4) ${ }^{32} \mathrm{P}$ 摂取率の測定}

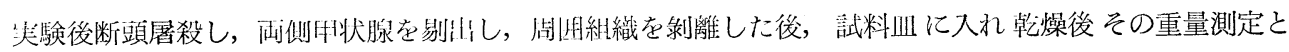
Geiger-Müller Counter に上る放射能測它を行なつた。更に胸腺及び血液の一部を採つて同様乾燥重量と 放射能測定を行なつた，尚この際の $\beta$ 線自己收收梁は $1 \%$ 以下であつた。 


\section{2. 実 験 成 績}

\section{1) TSH 反応性の指標}

TSH $0.1 \mathrm{JSu}$. を腹腔内注射後 4 時間で ${ }^{32} \mathrm{P} 10 \mu \mathrm{c}$. 注射, 更に 2 時間後屠殺し, 両側甲状腺及び脑腺, 血

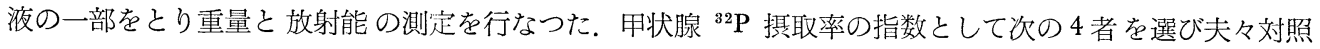
群に対する TSH 投与群の反応比率をみると第 1 図の如く， a) 甲状腺の全放射能では2.14倍，b）甲状腺 重量当りの放射能では 2.11 倍, c) 甲状腺重量当りの放射能/胴腺重量当りの放射能では3.37倍, b) 甲状 腺重量当りの放射能/血液重量当りの放射能では2.17倍となつた，反応の個体差により分散をも考慮し最も 簡単な甲状腺の全放射能を指数として採用する事にした。

\section{第 $\mathbf{1}$ 図 TSH 反応性の指数}

a) Thyroid $\mathrm{cpm}$

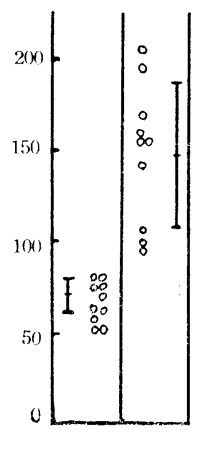

Cont. TSH b) Cpm/mg.

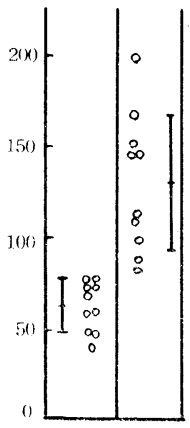

Cont. TSH c) $\frac{\text { Cpm } / \mathrm{mg} \text {. Thyroid }}{\mathrm{Cpm} / \mathrm{mg} \text {. Thymus }}$

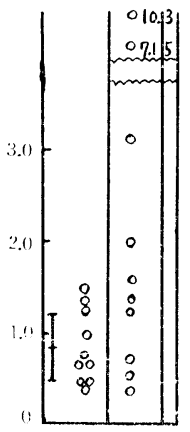

Cont. TSH d) $\frac{\text { Cpm/mg. Thyroid }}{\text { Cpm/ng. Blood }}$

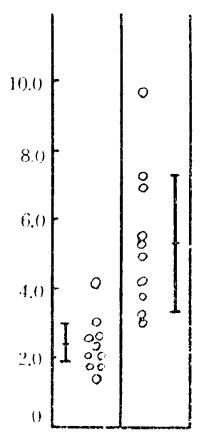

Cont. TSH

\section{2) 甲状腺 ${ }^{32} \mathrm{P}$ 摂取の時間的推移}

${ }^{32} \mathrm{P} 25 \mu \mathrm{c}$. 注射後, 甲状腺全放射能の時間的推移 は第 2 図の如く, 略々 2 時間で最高に達した。

\section{3) TSH 作用の時間的推移}

TSH を腹腔内に $0.1 \mathrm{JSu}$., 又は心内に $0.05 \mathrm{JSu}$. 投与し，一定時間後に ${ }^{32} \mathrm{P}$ を注射し，更に 2 時間 後甲状腺剔出を行なつた。 ${ }^{32} \mathrm{P}$ 摂取率が最高に達す る時間及びその際の対照に対する比は第 3 図に示す 如く, a) TSH の腹腔内投与後は 4 時間で2.34倍, b) TSH の心内投与後は 6 時間で 1.96 倍であつた.

\section{4) $\mathrm{TSH}$ 投与 2 時間後に ${ }^{32} \mathrm{P}$ を投与した場合の時} 間的推移

前述の ${ }^{32} \mathrm{P}$ 摂取率曲線と TSH 作用曲線の最高に達する時間を一致させる為に TSH 党腹腔内に $0.1 \mathrm{JSu}$. 投与後 2 時間で ${ }^{2} \mathrm{P}$ を注射し，以後甲状腺放射能の侍間的推移をみると，第 4 図の如く TSH 投与群と対

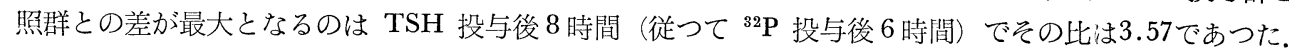

\section{5） TSH 亡 ${ }^{32} \mathrm{P}$ を同時投与した場合の時間的推移}

TSH 在腹腔内に $0.1 \mathrm{JSu}$.，又は心内に $0.05 \mathrm{JSu}$. 投与すると同时に ${ }^{32} \mathrm{P}$ を注射した場合の時間的推移は 第 5 図の如く，腹腔内投与心内投与共に注射後 6 川年閏で刘照との差が最大となり，その比は前者では対照の 3.09 倍, 後者では2.94倍であつた。
第 2 図 甲状腺 ${ }^{32} \mathrm{P}$ 提取の時間的推移

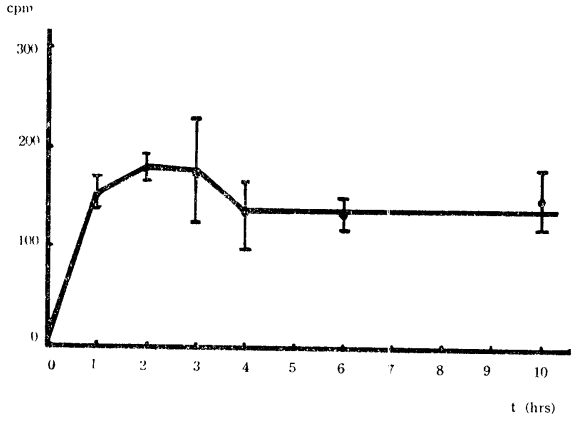


第3 図 TSH 作用の時間的推移

a) TSH 腹腔内投与

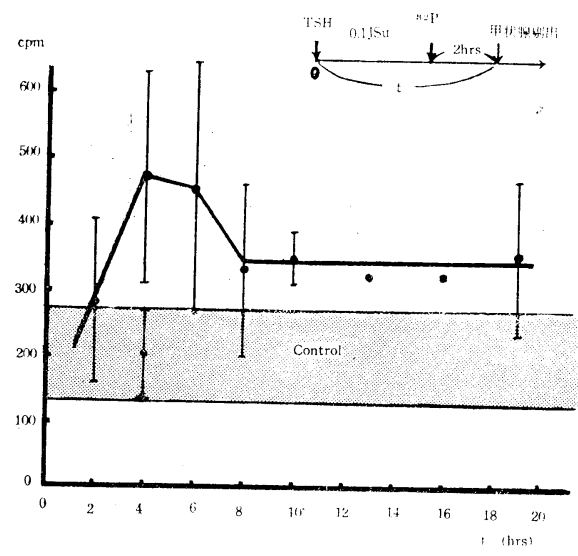

6) $\mathrm{TSH},{ }^{32} \mathrm{P}$ 同時投与 6 時間法による用量反応曲 線

$\mathrm{TSH}$ と ${ }^{32} \mathrm{P}$ を同時に腹腔内又は心内に投与し， 6 時間後に甲状腺 ${ }^{32} \mathrm{P}$ 摂取率を測定する方法 (同 時投与 6 時間法）による用量反応曲線は第 6 図の如 くで，感度をみると，腹腔内法，心内法共に 25 $\mathrm{m} \mathrm{JSu}$. 投与群以上で対照群と有意の差が認められ た. 又，精度指数入は腹腔内法では 0.44 ，心内法で は0.54であつた。

7) Thyroxine 投与雛を用いた場合の用量反応曲 線

内因性 TSH 分泌を抑制して投与 TSH に対す

第 5 図 $\mathrm{TSH},{ }^{32} \mathrm{P}$ 同時投与の時間的推移 a) $\mathrm{TSH}$ 腹腔内投与

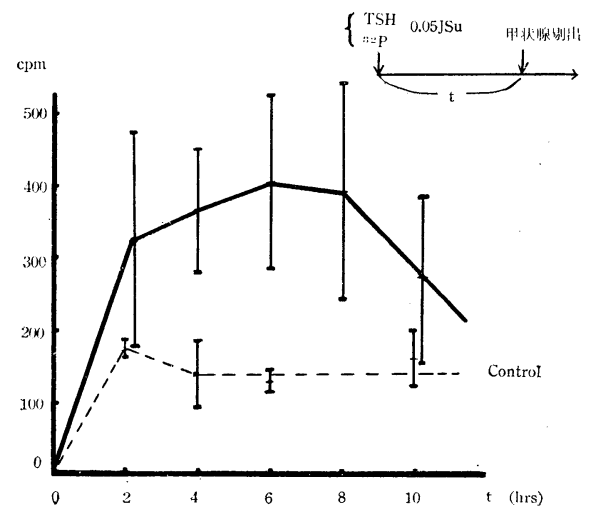

第 3 図 TSH 作用の時間的推移

b) TSH 心内投与

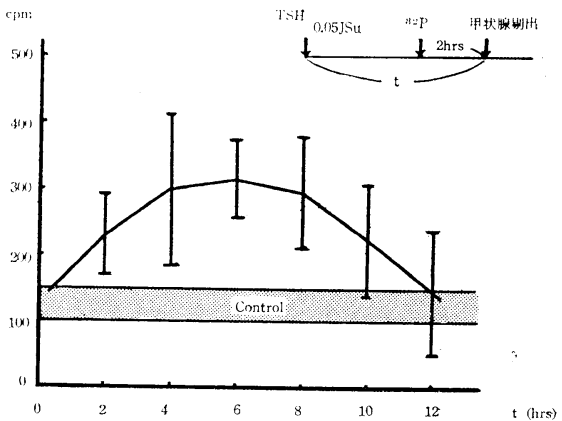

第 4 図 TSH 投与 2 時間後に ${ }^{32} \mathrm{P}$ を投与した場 合の時間的推移 ( TSH 腹腔内投与)

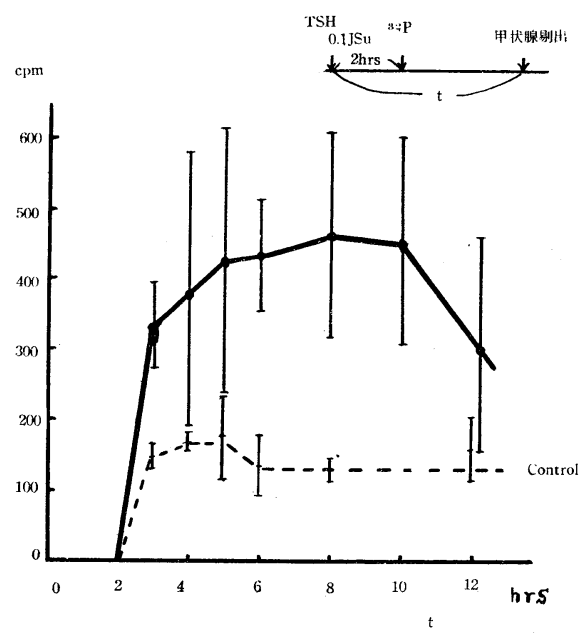

第 5 図 TSH, ${ }^{32} \mathrm{P}$ 同時投与の時間的推移

b) $\mathrm{TSH}$ 心内投与

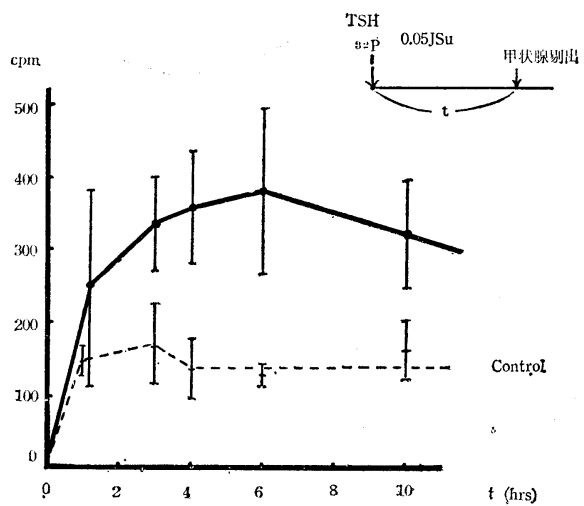


第 6 図 用量反応曲線

a) TSH 心内投与法

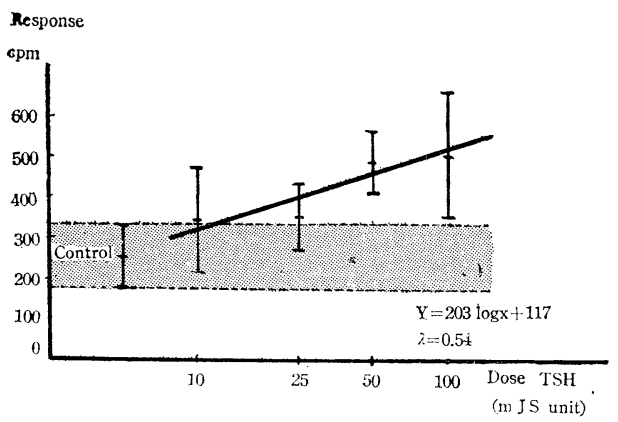

る感度を高める目的でL-thyroxine $30 \mu \mathrm{g}$. を 1 日 1 回 3 日間皮下注射した初生雛を用いた場合の前記心 内同時投与 6 時間法での用量反応曲線は第 7 困の如 く有意の差が認められるのは $25 \mathrm{JSu}$. 以上であり又 入は0.45であつた。

\section{3. 小 括}

初生雏甲状腺の ${ }^{32} \mathrm{P}$ 摂取能を指標とした $\mathrm{TSH}$ Bioassay に就き検討した結果次の知見を得た。

1) TSH 反応性は分散及び手技の簡便さを考愿 し，甲状腺の全放射能を指標とするのが最良であつた。

2) 甲状腺の ${ }^{32} \mathrm{P}$ 摂取率は ${ }^{32} \mathrm{P}$ 投与後 2 時間で最大に達した.

3) TSH 作用は腹腔内投与後 4 時間，心内投与後 6 時間で最大に達した.

4) ${ }^{32} \mathrm{P}$ と TSH の投与時間の関係に就いては検定時間及び手技の点から考光， ${ }^{32} \mathrm{P}, \mathrm{TSH}$ 同時投与 6 時 間後甲状腺の ${ }^{32} \mathrm{P}$ 揕取率を測定する方法が最も勝れていた。

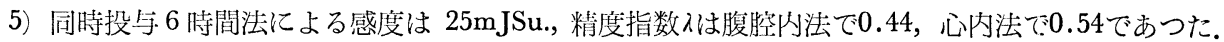

\section{II マウスの血中 ${ }^{131}$ I 放出を指標とした TSH Bioassay に関する検討}

1958年 McKenzie ${ }^{12)}$ は in vivo でマウスの血中 ${ }^{131} \mathrm{I}$ 放出が TSH により促進される事稑づく Bioassay を発表したが，内因性 TSH 抑制の目的で投与する L-thyroxine と TSH 反応性との関係等に就いて検討 を加え，更に本法の改良を企図し，以下の垁験を行なつた。

\section{1. 実験材料並びに方法}

\section{1) 検定動物}

阪大微研純系動物飼育所より入于せる $\mathrm{ddO}$ 系雌マウスで生後約 4 週を経た体重 14 ～16gのものを使用し， オリエンタル酵母固型飼料 $\mathrm{MF}$ のみで飼育した。 又飼育並びに笑験操作は常に $20 \sim 23^{\circ} \mathrm{C}$ の恒温室で行な つた.

2) ${ }^{131} \mathbf{I}$

生食水 $0.5 \mathrm{ml}$. Nに Carrier free $\mathrm{Na}^{131} \mathrm{I} 10 \mu \mathrm{c}$. 含付する様淍獘し，腹腔内に注射した。

$$
\text { 第38炎 符 } 6 \text { 多 }
$$




\section{3) L-thyroxine}

生食水 $0.2 \mathrm{ml}$. 中に L-thyroxine $10 \mu \mathrm{g}$. を含有する様調整し頸部皮下に注射した.

\section{4) 標準 TSH}

Pretiron (Schering 社製) を生食水 $0.5 \mathrm{ml}$. 中に所要濃度が含有する様調整し，尾静脈より注入した。

\section{5) 実験方法}

前処置として ${ }^{131} \mathrm{I} 10 \mu \mathrm{c}$. を投与し， 4 時間後に L-thyroxine $10 \mu \mathrm{g}$. を投与, 2 回投与の場合は 24 時間後 再び L-thyroxine $10 \mu \mathrm{g}$. を注射した.

1〜6 日後マウスを軽いエーテル麻醉下におきツベルクリン注射器を内眼角から眼球に沿つて後下方に刺 入し, 血液 $0.1 \mathrm{ml}$ 。を採取, その放射能を well-type scintillation counter で測定した. TSH 反応性の算 出には次式を用いた。

$\frac{\mathrm{TSH} \text { 投与後の血液 } 0.1 \mathrm{ml} \text { 中の放射能 }(\mathrm{cpm})}{\mathrm{TSH} \text { 投与前の血液 } 0.1 \mathrm{ml} \text { 巾の放射能 }(\mathrm{cpm})} \times 100$

\section{2. 実 験 成 績}

第 8 図 $T_{4}$ 投与による血中 F $^{131} 1$ 放射能の経時的变化
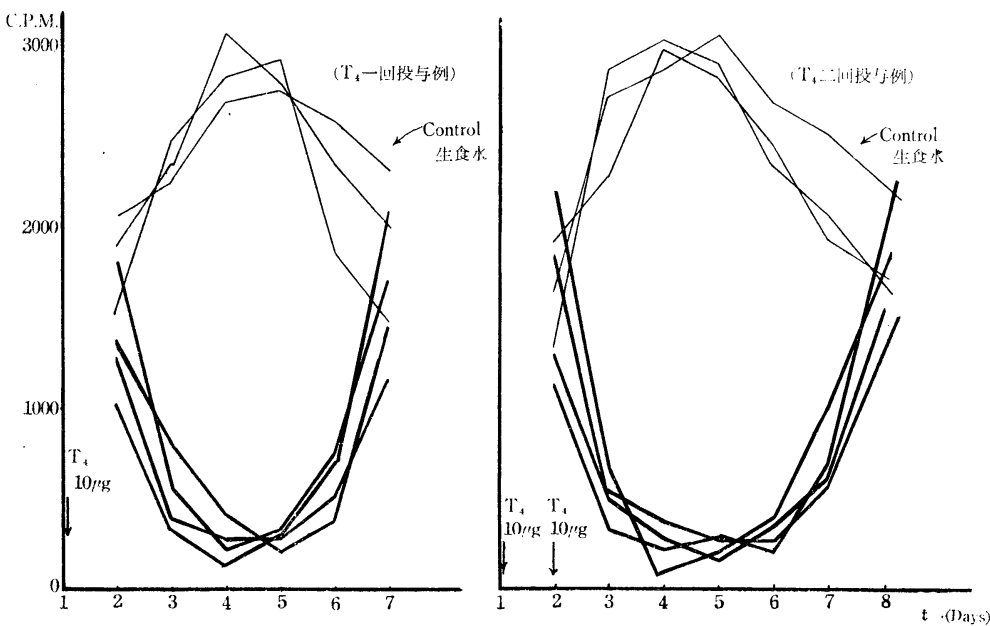

1) L-thyroxine 投与による血中 ${ }^{181}$ | 放射能の 経時的変化

前処置として投与した L-thyroxine の内因性: TSH 分泌汶刘する抑制㕮果を血中 ${ }^{191}$ I 放射能を 指標としてみた所第 8 図の如く, L-thyroxine 1 回投与では略々第 5 日迄抑制効果がみられ，2 回 投与の場合は第 6 日迄抑制の持続をみた。

\section{2) TSH 作用の時間的推移}

TSH $4 \mathrm{mJSu}$. 静注した場合の血中放射能の将 間的推移をみると第 9 図の如く投与後 2 時間で最 高に達したので，TSH 投与後 2 時間の血中 ${ }^{131} \mathrm{I}$ 放射能を測定する様にした。
第 9 図 TSH 作用の時間的推移 ( $4 \mathrm{mJSu}$. 静注例)

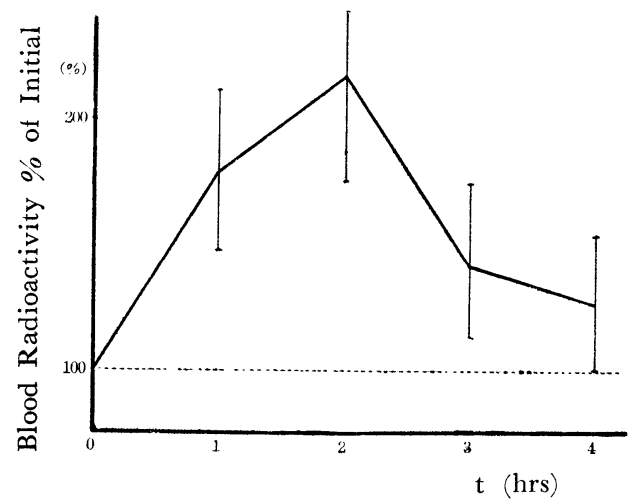




\section{3) L-thyroxine 投与後の TSH 投与時期とその TSH 反応性}

第 1 日目に ${ }^{131} \mathrm{I}$ 及び L-thyroxine 1 回投与の前処置をし, 第 2 日目から第 4 日目迄の各時期に於て夫々 $\mathrm{TSH} 4 \mathrm{mJSu}$. 投与した 3 群のマウスに就て，夫々の TSH 反応性を比較してみると前処置からの経過日 数が少ない程 TSH 投与による血中放射能の増加率が大で，第 2 日目に TSH を投与した場合，TSH 反応 性が最も大であつた。

\section{4) 前処置後の各測定期時に於ける検量曲線の比較}

前述の成績に基づき前処置後の各測定時期に於ける夫々の用量反応曲線に就て，その精度を比較し，第10 図及び第 1 表の如き結果が得られた。即ち，前処置後の TSH 投与時期が早い程検量曲線の回帰係数 (b) は 大となるが，それに伴い各用量に於ける反応度の分散も大となる傾向がある．然し後者よりも前者の方がそ の増加度大なる為, 結局精度指数としては勝れた結果となつた.

第 1 表 Assay Date による精度の比較

\begin{tabular}{|c|c|c|c|c|c|c|}
\hline \multirow[b]{2}{*}{ Assay date } & \multirow{2}{*}{ Assay 数 } & \multirow{2}{*}{ Dose 数 } & \multirow{2}{*}{$\begin{array}{l}\text { 標準偏差 } \\
\text { の平均値 }\end{array}$} & \multirow{2}{*}{$\begin{array}{c}\text { 回㷌係数(b) } \\
\text { の平均値 }\end{array}$} & \multicolumn{2}{|c|}{$\lambda$} \\
\hline & & & & & 平均值 & Range \\
\hline 第 2 日 & 3 & 5 & 66.5 & 271.4 & 0.24 & $0.17 \sim 0.29$ \\
\hline 第 3 日 & 5 & $2 \sim 5$ & 53.7 & 168.9 & 0.31 & $0.21 \sim 0.38$ \\
\hline 第 4 日 & 4 & $3 \sim 5$ & 39.5 & 119.5 & 0.35 & $0.20 \sim 0.46$ \\
\hline 第 5 日 & 3 & $2 \sim 4$ & 57.8 & 140.2 & 0.43 & $0.26 \sim 0.58$ \\
\hline
\end{tabular}

3. 小

括

$\mathrm{ddO}$ 系マウスを用いその血中 ${ }^{131} \mathrm{I}$ 放出を指標 とせる TSH Bioassay に就いて検討した結果次 の知見を得た．1）前処置として投与した L-thyroxine による内因性 TSH の抑制効果は 1 回投 与では第 4 第 5 日目，2 回投与では第 4 第 6 日目に最大を示した，2）TSH 反応性の最大に達 するのは TSH 投与後 2 時間であつた．3）前処 置後の TSH 投与を第 2 日目に行なつた場合精度 は最も良好で，測定可能範囲は 1〜16mJSu. であ つた.

\section{III 牛甲状腺切片のヨード代謝を} 指標とした TSH Bioassay に関する検討

Bakke et al. ${ }^{13)}$ は in vitro で牛甲状腺切片の ${ }^{131} \mathrm{I}$ 放出率が medium に加えられた TSH で抑 制される事を報告し，その機序を利用した TSH

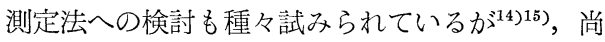
その機序には不明の点が多いので特にての点に検 討を加え，㐼せて本法の改良を企図して以下の実 験を行なつた。
第10図 Assay Date によるDose Response Curve の比輘

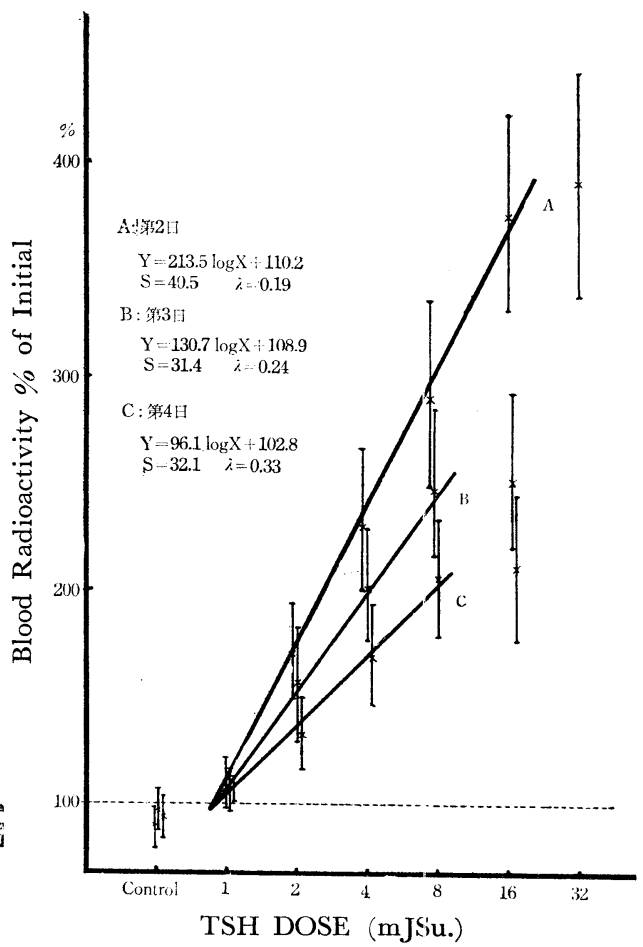




\section{1. 実験材料並びに方法}

\section{1) 牛甲状腺切片の作製}

屠殺後新鮮な牡牛甲状腺を約 $4{ }^{\circ} \mathrm{C} の$ Krebs-Ringer phosphate buffer $(\mathrm{pH}$ 7.35〜7.40) 中にてその中央 部より free hand で厚さ約 $0.5 \mathrm{~mm}$ の薄片を作製し，濾紙で水分を扸い取り Torsion balance で70〜80 $\mathrm{mg}$ の切片とした。

\section{2) Medium}

pH. 7.35 7.40 の Krebs-Ringer Phosphate buffer (KRP) に Carrier として沃度濃度が $10 \mu \mathrm{g} / \mathrm{dl}$. なる如く KI を添加し，又切片の摄取 ${ }^{131} \mathrm{I}$ の有機化阻止の目的で mercazole (中外製薬製) $1 \mathrm{mg} / \mathrm{dl}$. なる如く加えた。放射性ヨードの添加量は $0.2 \mu \mathrm{c} / \mathrm{ml}$. とした。又标集 TSH は pretiron (Schering 社製) 童 KRP で所要濃度に桸积して使用した。尚 TSH は Release phaseの medium のみに添加した。

\section{3) 実験方法}

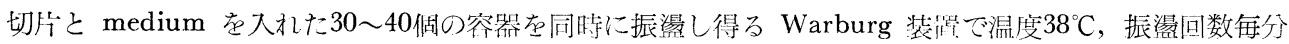
60回転, open で incubate した.

a) Uptake phase : 切片を ${ }^{131} \mathrm{I}$ 含杼 medium $3 \mathrm{ml}$. 中で1時閒 incubate した。

b) Release phase : Uptake phase 後切㸝の水分を滤紙で拭い取り，次で ${ }^{131}$ I 非含有 medium を200ml. ずつ入れた 3 個のビーカー中で約 1 秒閒ずつ順次に洗涤した後, 更に滤紙で水分を除去して，TSH 含有 medium ( ${ }^{131} \mathrm{I}$ 含有せず) $3 \mathrm{ml}$ 中に移し，4 時間 incubateした後, 切片を $10 \% \mathrm{NaOH}$ に溶解し, その 放射能と Release phase 後の medium $1 \mathrm{ml}$. 中の放射能及び Uptake phase 前の medium $1 \mathrm{ml}$. 中の放 射能を well-type scintillation counter で計測した。尚本実験に於ける放射能の回収率は 100.4 102.9\% であつた. 又切片は同一実験に於ては同一の牛甲状腺組織より作製し，一点に $5 \sim 6$ 侗の切片を充当した.

\section{2. 実 験 成 績}

\section{1) TSH 反応性の指標}

Uptake phase そ於ける切片の ${ }^{131} \mathrm{I}$ 濃縮能 (U) 及び Release phase に於ける切片の ${ }^{131} \mathbf{I}$ 放出率 (R) は次式により算出される。

$$
\mathrm{U}=\frac{\mathrm{T}+\mathrm{M}^{\prime}}{\mathrm{M}} \times 100 \quad \mathrm{R}=\frac{\mathrm{M}^{\prime}}{\mathrm{T}+\mathrm{M}^{\prime}} \times 100
$$

但し, $\mathrm{T}:$ Release phase 後の用状腺切片の放射能.

M : Uptake phase 前の medium $3 \mathrm{ml}$. 中の放射能.

$\mathbf{M}^{\prime}$ : Release phase 後の medium $3 \mathrm{ml}$. 中の放射能.

Bakke 等1314)15) は本法们於ける TSH 反応性の指標として R を採用しているが，私は Release phase に於ける切片の ${ }^{13} \mathrm{I}$ (蓄積) 保持能 $\left(\mathrm{U}^{\prime}=100-\mathrm{R}\right)$ とUの関係を検へた所第11図の如く両者の間には正の 相関々係が認みられた。従つて私は切片によ る差を可及的僅少にする為最初の ${ }^{131} \mathrm{I}$ 濃縮能 をも考虑に入れた新しいParameter $\mathrm{U}^{\prime} / \mathrm{U}$ を TSH 反応性の指標とし次式により 算出し た.

$$
\begin{aligned}
& \mathrm{U}=\frac{\mathrm{T}+\mathrm{M}^{\prime}}{\mathrm{M}} \times 100 \\
& \mathrm{U}^{\prime}=100-\mathrm{R}=\frac{\mathrm{T}}{\mathrm{T}+\mathrm{M}^{\prime}} \times 100 \\
& \therefore \quad \mathrm{U}^{\prime} / \mathrm{U}=\frac{\mathrm{T} \cdot \mathrm{M}}{\left(\mathrm{T}+\mathrm{M}^{\prime}\right)^{2}}
\end{aligned}
$$

第11図 Parameter U, $\mathrm{U}^{\prime}$ の関係

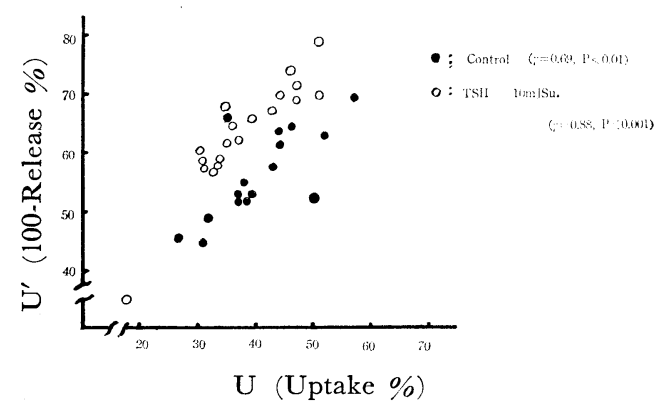


$2 U^{\prime} / U$ 及び R を指標とした場合の検舅曲線の比較

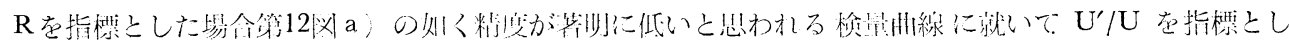

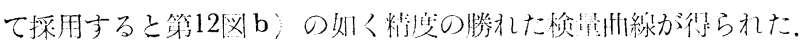

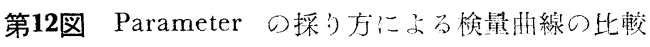
a) Parameter : Ró

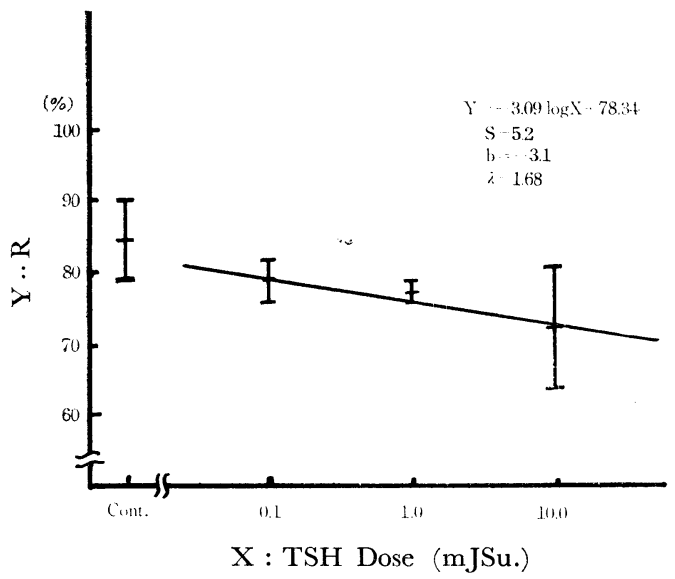

3. 小
第12図 Parameter の採り方による検莗曲線の比轌 b) Parametel: : U'/U

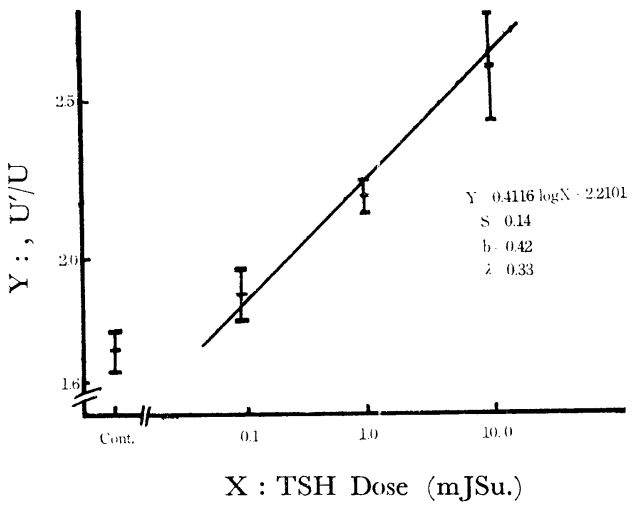

括

牛甲状腺切片のヨード代謝を指標とした TSH Bioassay の Parameter に関する検討を行ない次の知見を 得た． 1) 個々の切片の Uptake phase に於ける ${ }^{121} I$ 濃縮能（U）とRelease phase K於ける ${ }^{131} I$ (萻積) 保持能 $\left(\mathrm{U}^{\prime}\right)$ との間には正の相関々係が垫められた，2）従つて TSH 反応性の指標として U'/U を採用 し, 従来の ${ }^{131} \mathrm{I}$ 放出率 $(\mathrm{R})$ を指標とするよりも精度の改善が得られた. 3) 本改良法による確実な測定可 能籁囲は $10^{-2} \sim 10^{-4} \mathrm{JSu}$. であつた。

\section{IV in Vitro 及び in Vivo の測定による人並びに豚 TSH 反応性の比較}

TSH Bioassay の臨床応用に際しては標準 TSH と人 TSH の父态性の比挍並びに同一検体を 2 種以上 の方法によつて測定し，比較検討を行なう事が必要である。そてで人下䦚休よりの TSH 抽液に就いて私 の改良した in vitro 及び in vivo の 2 方法でこの点を検傠した。

\section{1. 実験材料並びに方法}

\section{1) 被検材料}

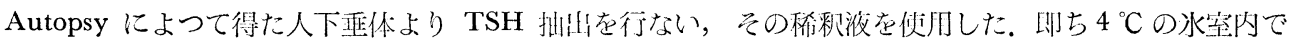
人下垂体の被膜を除去し，乳錰内で $3 \% \mathrm{NaCl}$ 溶液と其に磨砤して後遠沈し，その上澄を生食水で稀釈し 実験に供した。尚一部はての $2 \% \mathrm{NaCl}$ 溶液によつて得た TSH 抽出液を更に Bates et al. ${ }^{16)}$ の方法に準 じAceton 分画を行ないその粗人 TSH を先ず DEAE-G (Diethylaminoethyl Cellulose) Column そよ つて TSH 分画を精製し脱塩して後, てれを更に CM-G (Carboxymethyl Cellulose) Column で精製し たものを実験に供した.

\section{2) Bioassay}

Bioassay には in vitro の方法として牛甲状腺切牌のヨード代謝を指䌘とした收良法を，in vivo の方法 としてマウスの血中 ${ }^{131} \mathrm{I}$ 放出を指標とした改良法を用い，実験条件を可及的同一にする為，上記下垂体の 抽出液（一部はそれを更に精製したもの）に就いて同一日に同時測定を行なつた. 


\section{1) 豚 TSH と人 TSH の反応性の関係}

\section{2. 実 験 成 績}

a) 人 TSH（5 個の下垂体よりの抽出液を pool したもの）在 DEAE-G 及び CM-C により分離精製し たものと標準 TSH である豚 TSH 製剂 (Pretiron) の両者に就き in vitro の Bioassay 右倵みた所両者 の用量反応曲線は第13図a）の如く略々平行関係を示した。

b) 3 倜の人下垂体より $2 \% \mathrm{NaCl}$ 溶液で抽出し pool した人 TSH と豚 TSH とに就いて in vivoの

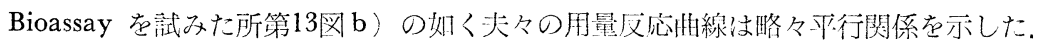

第13図 豚 TSH と人 TSH の反态性の関係 a) in vitro $\odot$ Bioassay

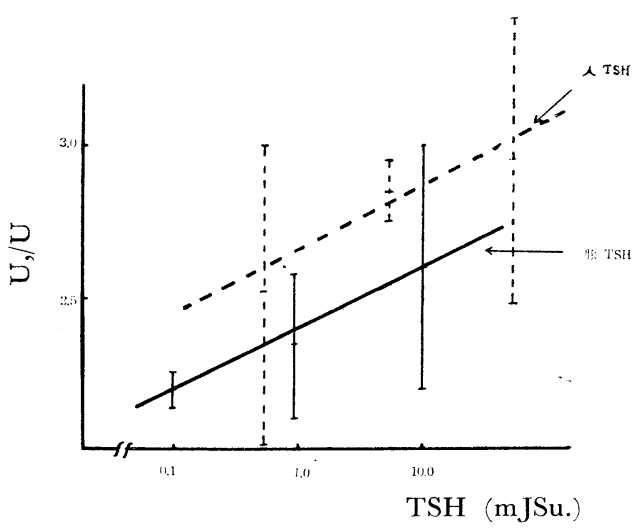

第 2 表 in vitro 证びに in vivo の Bioassay による人下垂体の TSH 活性比輍 (JSu./Pituitary)

\begin{tabular}{c|c|c}
\hline Bioassay & in vitro & in vivo \\
\hline 下垂体番号 & 1.25 & 1.1 \\
\hline 1 & 1.25 & 1.6 \\
2 & 12.8 & 6.6 \\
3 & 13.2 & 16.0 \\
4 & 22.8 & 25.6 \\
5 & \\
\hline
\end{tabular}

第13図 豚 TSH と人 TSH の反応性の阙係

b) in vivo $の$ Bioassay

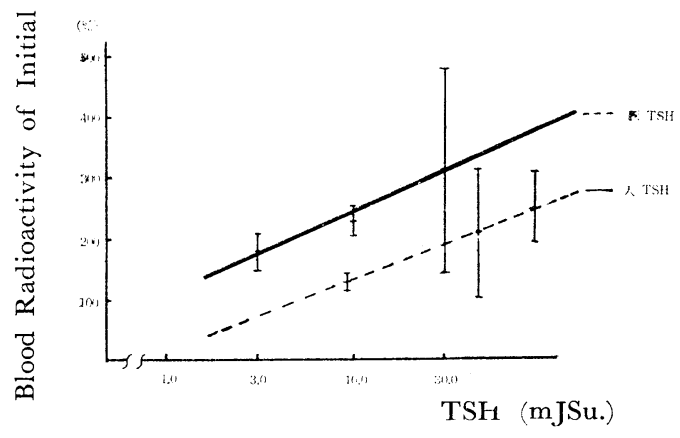

2) in vitro 及び in vivo の測定法による人下 垂体の TSH 活性比較

5 湖の人下垂体より夫々 $2 \% \mathrm{NaCl}$ 溶液で抽 出せる TSH 液に就いて in vitro と in vivo の Bioassay を同時に行つた結果，第 2 表の如く雨 方法での測定值の開には略々平行関係がみられ た.

\section{3. 小 括}

人下垂体より抽出せる人 $\mathrm{TSH}$ に就いて牛用

状腺切片のヨード代塮を指標とせる in vitro の改良法とマウスの血旪 ${ }^{121} \mathrm{I}$ 放出を指栖とせる in vivo の 改良法とを比較検討し，次の知見を得た。

1) in vitro 及び in vivo の Bioassay そ標準 TSH として用いる豚 TSH と人 TSH の反応性には略 々平行性が見出された.

2) 人下垂体の TSH 抽出液に就いて in vitro 及び in vivo の両方法で TSH 活性を測定したが，両 測定值の間には殆ど差異が見られなかつた。

\section{V. 総括並びに考按}

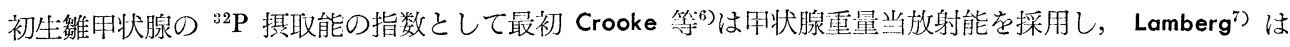
対照臓器として胸腺の放射能に対する比を採用したが，Greenspan ${ }^{8}$ は指数として甲状腺の全放射能，甲状 腺重量当放射能及び血液放射能に対する比の 3 者に就き $\lambda$ を検討した結果，甲状腺の全放射能を指標とする 
のが最良であると述べている。私の成䋶に於ても対照群に対するTSH 投与群の比率が最大であるのは〔甲 状腺重量当放射能/䏩腺重量当放射能了を指槽と子る場合であつたが，分散が著明に大となつた。そこで他 の指数の内，此率は略々同じであるが分散少なく且つ最も簡便な币状腺全放射能を指数として採用した。

${ }^{32} \mathrm{P}$ を腹腔内に注射した際の甲状腺掑取率の特關的推移は Crooke ${ }^{6)}$ の成績と略々一致した. TSH 作用が

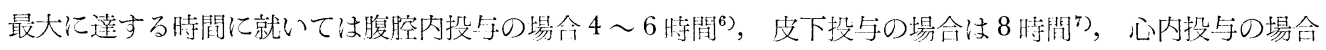
8 時閜 ${ }^{11}$ 等之報告されているが，私の成績で法腹腔内 4 時間，心内投与 6 時間であり (第 3 困)，諸家の報 告との差異は使用 TSH 量, 雛の種類等により生じ得るもの之思われる。 ${ }^{32} \mathrm{P}$ と TSH の投与時閒の関係 に就いては TSH 投与後 4 時間で ${ }^{32} \mathrm{P}$ 投与, 更に 2 時闆後に甲状腺剔出を行なう法 ${ }^{6}$, TSH 投与後 7 時間

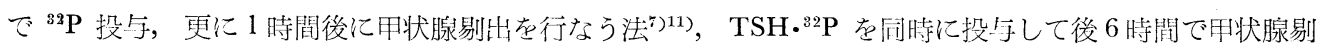
出を行なう法8)等が報告されている。然し，私の成績によると(1) TSH 腹挖内投与 2 時閔後又は心内投与 4 時間後に ${ }^{32} \mathrm{P}$ 投与，更に 2 時問後印状腺剔出在行なつた場合 (第 3 図) (2) ${ }^{32} \mathrm{P}$ 摄取と TSH 作用の最大に 達する時閪を一致させる為に TSH 腹腔内投与後 2 時閐で ${ }^{22} \mathrm{P}$ 投与, 更に 6 㭙開後に甲状腺剔出を行なつ た場合（第 5 図）(3)或いは TSH の腹膑内又は心內投与と同時に ${ }^{32} \mathrm{P}$ を投与した場命（第 5 図）に於て対 照に対する比率と分散を比較すると(2が最も良く次で(3)，(1)の順となつた。

然し Bioassay は手技が簡便にして且つ検定時閏の短い程良い為てれを考雇すれば, (3) TSH, ${ }^{32} \mathrm{P}$ 同時 投与 6 時間法が最も勝れているといえる ${ }^{17)}$. TSH 投与法に就いて Greenspan $\left.{ }^{8}\right)$ ( 心内投与の方か腹腔内又 は皮下投与よりも勝れているとしたが，私の成績によると精度及び感度の点では大差が認められなかつた。 更に心内投与は手技が困難にして且つ投与する検体容量が腹腔内の場合より少ないという久点があり生物学 的検定法の諸条件 $\left.{ }^{18}\right)$ を勘案すると両者の優劣は早急に断じ難い.

又，甲状腺ホルモンを投与して，内因性 TSH 分泌を抑制する事により TSH Bioassay の感度を高めよ うとする試みも数多く為されているが ${ }^{1219}$ ，私の成績では L-thyroxine 前処置により分散は少なくなるが TSH に対する反応性は低下した。 ての一因として大量の L-thyroxine 処置により外因性 TSH 効果が減 弱するという報告20021)も考慮し得る。従つて前処置しない場合に比し感度, 精度共に改善される結果は得ら れなかつた。

次に in vivo での ${ }^{131}$ I-labelled thyroid hormone の血中放出に基づく TSH Bioassay に就いては Adams and Purves (海猽) ${ }^{2223)}$ を初めとして Gilliland and Strudwick (雛) ${ }^{24)}$ 及び Bates and Cornfield (駣) 25)等により種々の方法が報告されているが, 1958年 McKenzie ${ }^{12)}$ の発表せるマウスの血中 ${ }^{131} \mathrm{I}$ 放出を指標と する方法はてれらの内最も勝れているとされている。 内因性 TSH 分泌抑制の目的で行なう L-thyroxine 投与の前処置後 TSH を投与する迄の期間に就いては McKenzie ${ }^{12)}$ 及び山崎 ${ }^{2627)}$, 鎮目 ${ }^{28)}$ 等は第 4 〜第 6 日目としているが，私の成績からもマウスの内因性 TSH 分泌の抑制が最大に達するのは第4 第 6 日目で あつたから理論的にはての期間に測定を行ならのが適当と考无られる。然し私の成績では前処置後の時期が 早い程精度が勝れ，第 2 日目に TSH 投与を行なつた場合の精度が最も優秀であつた ${ }^{29}$. ての原因としては 1) L-thyroxine に上る内因性 TSH の抑制効果が充分効いているよりも適度に弱く效いている時の方が外 因性 TSH の反応性が大となる可能性 2) 投与した ${ }^{131} \mathrm{I}$ によてマウスの 甲状腺が多少損智される為 ${ }^{181} \mathrm{I}$ 投与後の期日が短い程損賃程度は少なく, 従つて甲状腺の活性が高いので TSH に対する反応性が大となる 可能性の 2 つが考光られる.

然し，投与 ${ }^{131} \mathrm{I}$ は $10 \mu \mathrm{c}$. であり Goldberg，Chaikof ${ }^{30) 31)}$ 等によるこの程度の ${ }^{121} \mathrm{I}$ では中状腺及び下垂体 が損傷されないと報告されており，又第 8 図からみても分る様に L-thyroxine の抑制効果の無くなる第 6 日目頃より血中 ${ }^{131} \mathrm{I}$ 放射能が渐次再び上昇する事から考学て 2) の可能性は少ない，一方，大量の thyroxine により外因性 TSH の反応性は減弱するといら報告 ${ }^{20221)}$ が見られ，又私の成績からも前述した如く初 生雏甲状腺の ${ }^{32} \mathrm{P}$ 摂取能を指標とした場合 L-thyroxine 投与により TSH 作用がかえつて低下した事から も1）の可能性が大である. 私の改良せる方法による精度指数入は0.17〜0.29, 感度は $1 \mathrm{mJSu}$. で McKenzie 12)の報告せる感度より稍々劣つていたがてれは検体動物種の差によるものと考えられる. 
次に in vitro で牛甲状腺切片のヨード代謝を指標とする方法の原理に就いて 明確な解糔はなされていな いが永田 ${ }^{15}$ も指摘している如く TSH が甲状腺切片のヨード保持能をたか子る為, Release phase 亿於け る ${ }^{131} \mathrm{I} の$ medium への放出率 (R) が抑制されるものとみられ，従つて Release phase に於ける切片の ヨード保持能 $\left(\mathrm{U}^{\prime}\right)$ は100-Rで表わされる，然るに，同一実験行て同一牛甲状腺より作製した切片でもそ の ${ }^{131} \mathrm{I}$ 保持能は Uptake phase (U) でき Release phase ( $\left.\mathbf{U}^{\prime}\right)$ でも可成りの変動が見られ，てれは恐ら く倜々の切片作製を必ずしも均一传する事が出来ない為と思わ祅る。従つて Release phase で TSH 効 果をみる場合にる各切片間に於けるヨード湄縮能の変動を可及的避けるのが望ましい. 今 TSH を加えない で Uptake phase でのヨード濃縮能 (U) と Release phase でのそれ（U'）をみると両者の相関々係が見 られたので各切片閆の変動を出来るだけ少なくする parameter として U'/U を採用するのが合理的と考え られる。事実, 前述の成績の如く ${ }^{191} \mathrm{I}$ 放出率を指標とすると一見精度が非常に低いと思われる場合でる $\mathrm{U}^{\prime} / \mathrm{U}$ を指標とすると精度の著しく改善される例が得られた。 又本法の測定可能簿囲は $10^{-2} \sim 10^{-5} \mathrm{JSu}$. と する報告 ${ }^{15) 22}$ が多いが私の成績ではこの範囲が毎常測定可能とは言い難く確実な測定可能範囲は $10^{-2} \sim 10^{-4}$ JSu. であつた.

以上，in vitro 及び in vivo の3 方法に就いて私の実験成績を吟味し乍ら考察を加えたが， a）牛甲状

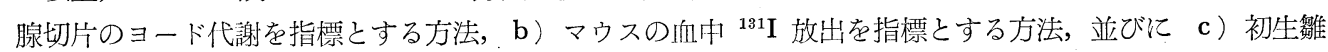
甲状腺の ${ }^{32} \mathrm{P}$ 摂取能を指標とする方法の内そのいずれが優秀であるかを Segaloff 等 ${ }^{\left.13) 33)^{34}\right)}$ の提唱する Bioassay の条件の個々に就いて私の成績から比較検討してみる。

1) 感度の点では a) が最も優り, 次でb） c) の順となる.

2）精度及び再現性の点に関しては諸家の報告 ${ }^{15226)}$ 及び私の経験 ${ }^{35)}$ からもb）が最も優り, 次で a ） c) の順となる。

3) 経済的及び迅速な点ではa）が最も有利であり，簡便性の点では 3 者いずれとも判定し難い.

従つて初生倠甲状腺の ${ }^{32} \mathrm{P}$ 摂取能を指標とする方法では人血中 TSH 活性測定等の臨床応用は困難であ ろう. 次に Bioassay の臨床応用に際してはその標準 TSH と人 TSH との反応性に平行性の存する事が 不可欠の条件であるが私の検討せる成績では両者の用量反応曲線に平行性が見出され，in vitro 及び in vivo の両法共に臨床応用の可能なる事が示唆された。 然してれは Bates et al. ${ }^{16)}$ の報告とは相違した結果 であるが，彼のは牛 TSH と人 TSH との反応性に就いて検討したもので，且つ Bioassay も私のそれと は異なる為とも思われる。 又，人下垂体の TSH 活性を in vitro と in vivo の両法で同時測定した結果 両測定值の間には略々平行関係が認められた。

尚人下垂体中の TSH 含量に就いては Bakke et al. ${ }^{36) 38339)}$ の牛甲状腺切片の重量法による報告並びに Wilhelmi ${ }^{37)}$ の白色レグホンの甲状腺 ${ }^{32} \mathrm{P}$ 摂取率法による報告とは稍久異なるがてれは抽出法や Bioassay の相違する為とも考えられる。

以上の観点から牛甲状腺切片のヨード代謝を指標とする in vitro の方法及びマウスの血中 ${ }^{131} \mathrm{I}$ 放出を指 標とする in vivo の方法共に臨床応用には可能であるが微量な TSH 測定には前者が適し，其他の臨床応 用面例えば異常 TSH 等の検索には後者が有用である事が明らかとなつた。

\section{結 論}

in vivo と in vitro の TSH Bioassay 飞就き基整的研究を行ない䠦床応用への可能性を検討し，以下の 如き結果を得た。

1) 初生雊甲状腺の ${ }^{32} \mathrm{P}$ 摂取能を指標とする方法は $\mathrm{TSH}$ と ${ }^{33} \mathrm{P}$ の腹腔内同時投与 6 時間後甲状腺 の全 放射能を測定する方法が最も優れ，精度指数れは 0.44 , 感度は $25 \mathrm{mJSu}$. であつた。

2) マウスの血中 ${ }^{13}$ II 放出を指標とする方法は前処置の坛日 TSH 測定を行なう事により精度の改善を 認め, $\lambda は 0.24$, 測定可能範囲は 1〜16mJSu. であつた.

3) 牛甲状腺切片のヨード代謝を指標とする方法は新しい Parameter U'/U を TSH 反応性の指標とす 第38巻 第 6 号 


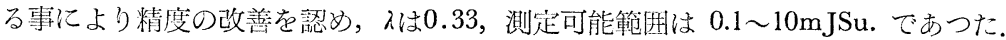

4) 人下垂体の TSH 抽出液に就いて in vitro と in vivo の方法で比較検討した結果，人 TSH と祭 準 TSH との反応性は略々平行を示し, 又雨方法の測定值の開にも平行関係が認められた。

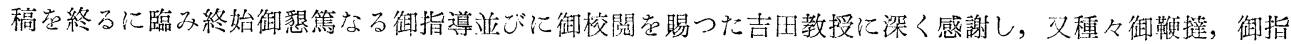
導を戴いた和田助教授，熊原，岩坪，宮井博士及び実験に御協力頂いた阪上学士に心汃ら感謝します。，又， Pretiron 在提供下さつた日独萫品汇潹謝します。

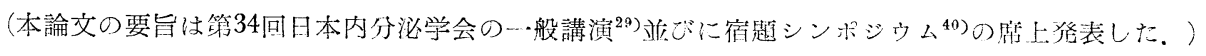
文献

1) Loeb, L, Basett, R.B. \& Friednan, H. : Proc. Soc. Exp. Biol. Med., $26: 860$, (1929 . 2) Aron, M. : C.R. Soc. Biol., $102: 682$, (1929).

3) De Robertis, E.D. : J. Clin. Endocrinol., $8: 956$, (1948). 4) D'Angelo, S.A. \& Gordon, A.S. : Endocrinol., $46: 39$, (1950). 5) Tala, P.: Endocrinol., $53: 474$, (1953). 6) Crooke, A.C. \& Matthews, J.D. : Giba Foundation Colloquia on Endocrinology, $5: 25$, (1953). 7) Lamberg, B.A. : Acta Med, Scandinav. Suppl. 279, (1953). 8) Greenspan, F.S., Kriss, J.P., Moses. L.E. \& Lew, W. : Endocrinol., $58: 767,(1956) . \quad 9)$ 鎮目和夫, 入江 実, 飯野史郎 : 最 新医学, $12: 23,(1957)$. 10) 置塩部三, 井上 康, 植田安雄 : 日本内分泌学会雑誌, $33: 126$, (1957). 11) 脇坂行一, 河野 剛, 山田光雄, 伊藤憲一, 野平信哉, 小林 功, 平井拓造 : 最新医学 $13: 1362$, (1958). $\quad 12)$ McKenzie, J.M. : Endocrinol., $63: 372$, (1958). $\quad$ 13) Bakke, J.L. \& Lawrence, N. : Endocrinol., $58: 531 ，(1956)$. 14) 小倉 一 : 日本内科学会雑誌, $48: 1045$, (1959). 15）永田 格：日本内分泌学会雑誌，35：1267，(1960). 16) Bates, R.W. \& Condliffe, P.G. : Recent Prog. Hormone Research, $16: 309$, (1960). 17) 宮井 潔, 千頭 隆, 岩坪治雄, 熊原雄一, 松尾美 泰：日本内分泌学会雑誌，33:126，(1957). $\quad 18)$ Segaloff，A.：Ciba Foundation Colloquia on Endocrinology, $5: 1$, (1953). 19) Gilliland, I.C. \& Strudwick, J.I. : Ciba Foundation Collquia on Endocrinology, $5: 25$, (1953). 20) Galli-Mainini, C. : Endocrinol., $29: 674$, (1941). 21) Cortell, R. \& Rawson, R.W. : Endocrinol., $35: 488$, (1944). $\quad 22)$ Adams, D.D. \& Purves, H.D. : Proc. Univ. Otago Med. Sch., $31: 38$, (1953). 23) Adams, D.D. \& Purves, H.D. : Endoclinol., $57: 17$, (1955). 24) Gilliland, I.C. \& Strudwick, J.I. : Clin. Sci., $12: 265$, (1953). $\quad 25)$ Bates, R.W. \& Cornfield, J. : Endocrinol., $60: 225$, (1957). 26) 山崎鋭一：綜合医学，17:571，(1960). 27) E. Yamazaki, A. Noguchi, S.Sato \& D.W. Slingerland : J. Clin. Endocr. \& Metab., $21: 1127,(1961)$ 28) 鎮目和夫 : 日本内分泌学会雑誌, $37: 325,(1961)$. 29) 土岐泰久, 阪上 明, 宮井 潔, 吉田常雄 : 日本内 分泌学会雑誌, 37 : 104，(1961). 30) Goldberg, R.C. \& Chaikoff, I.L. : Endocrinol., 46:91, 1950. 31) Goldberg, R,C., Chaikoff, I.L., Lindsay, S. \& Feller, D.D. : Endocrinol., $46: 72,(1950) . \quad 32)$ 辻昇三 日本内分泌学会雑誌，37：315，(1961). 33) Albert, A. : Ann. New York Acad. Sc., 50:466, (1949). 34) Lamberg, B.A. : Acta Endocrinol., $18: 405 ，(1955) .35)$ 土㞳泰久，宮井 潔，隠 岐和之，中原司朗，上小沢道弘，松尾美泰：日本内分泌学会雑誌，36:250，(1960). 36) Bakke, J.L. \& Lawrence, N.L. : J. Chin. Endocrinol. \& Metab., $19: 35$, (1959). $\quad 37)$ Wilhelmi, A.E. : Ciba Foundation Colloquia on Endocrinology, $13: 25,(1960) . \quad 38)$ Bakke, J.l.. \& Lawrence, N. : Endocrinology Society Meeting, June. 9-11, (1960). 39) Bakke, J.L., Knudtson,K., Lawrence, N. \& Needmham, G. : Endocrine Society Meeting, June 9-11，(1960). 40) 吉田常雄, 熊原雄一：日本内 分泌学会雑誌, $37: 340,(1961)$. 